Papers and Proceedings of the Royal Society of Tasmania, Volume 108

(ms. received 11.3 .1974 )

\title{
LOWER DEVONIAN BRACHIOPODS FROM THE POINT HIBBS LIMESTONE
}

\section{OF WESTERN TASMANIA}

by P.G. Flood

Geology Department, University of New England, Armidale, N.S.W.,

(now University of Queensland, Brisbane, Queens1and)

(with two text-figures and four plates)

\section{ABSTRACT}

Fourteen brachiopod species belonging to the following genera are described from the middle Lower Devonian (Siegenian) Point Hibbs Limestone, Tasmania: Schizophoria, Isorthis, Cymostrophia, Megastrophia, Hipparionyx (?), "Chonetes", Machaeraria, Uncinulus, Hebeotoechia, Atrypa, Meristelza, Athymis, Cyrtina, and Acrospirifer.

Megastrophia hizzae sp. nov., Hebeotoechia hibbensis sp. nov., and Acrospirifer banksi $\mathrm{sp}$. nov. are erected. This fauna displays close affinity to faunas recorded from the Coopers Creek Formation, the Lilydale Limestone, and the Tabberabbera Formation of Victoria, and the Baton River Beds of New Zealand.

INTRODUCTION

The Point Hibbs Limestone is a constituent formation of the Spero Bay Group: a succession which crops out along the shoreline north of Point Hibbs and along the northern shore of Spero Bay (Figure 1). The succession has been described by Banks (in Spry and Banks, 1962), and by Banks, Ahmad and Ford (1960). The sequence is illustrated in figure 2 .

The fauna of the Limestone has been mentioned by several authors: Hil1, 1942; Banks in Spry and Banks, 1962; Hil1, 1967; Banks in Talent and Banks, 1967; Philip and Pedder, 1967; Jel1 and Hi11, 1970; Strusz, 1972; and Picket, 1972.

This taxonomic study is based on two small collections of brachiopods, numbering about 350 specimens. The University of New England material was collected by A.E.H. Pedder and G.M. Philip in February, 1964, and is stratigraphically located mainly within the interval 45 to 90 metres above the base of the Point Hibbs Limestone (UNE macrofossil localities 455 and 456 respectively). These specimens have been assigned UNE numbers. The second collection, part of the University of Tasmania's fossil collection, includes brachiopods collected by M.R. Banks while mapping the Point Hibbs 1-mile Sheet. Specimens in this collection cannot be precisely located within the stratigraphic section. These specimens are assigned UT numbers. Attempts to locate a third suite of fossils, submitted to Robert Etheridge Jnr. in 1914 (mentioned in Hil1s, 1914, p.9), proved unseccessful. Neither the Australian Museum, nor the Geological Survey of New South Wales, knows of its whereabouts (in litt., 9 September, 1969; 21 October, 1969 respectively).

\section{FAUNA, AGE AND CORRELATION}

The brachioped fauna of the Point Hibbs Limestone includes Schizophoria sp. cf. S. provularia (Maurer), Isorthis sp. cf. I. festiva Philip, Cymostrophia be Zlarugosa Talent, Megastrophia hizzae sp. nov., Hipparionyx (?) sp., "Chonetes" sp., Machaeraria sp. cf. M. formosa (Hall), Uncinulus (?) globosus Talent, Hebeotoechia hibbensis sp. nov. Atrypa sp. cf. A. reticularis (Linnaeus), Meristelza sp., Athyris (?) sp., Cyrtina heteroclita (Defrance), and Acrospirifer banksi sp. nov. 


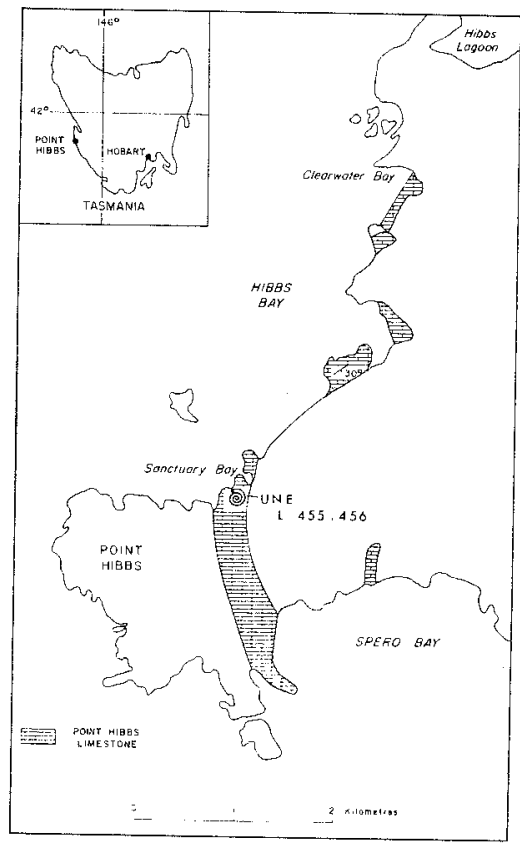

FIC. 1. - Map showing the distribution of the Point Hibbs Limestone.

Limestone (Philip and Jackson, 1970), and from the Garra Formation (Druce, 1970).

Intercontinental Lower Devonian biostratigraphic correlations have been under review (Savage, 1973b) since Carls (1969) demonstrated that Rhenish section was placed too low relative to the Bohemian section of the Lower Devonian. Therefore it has become necessary to reassign a Middle and Upper Siegenian age respectively to the Upper Yeringian and Tabberabberan Brachiopod Faunas. The Point Hibbs brachiopod fauna would be Middle to Upper Siegenian in age.
This fauna shows similarities with faunas described from the Coopers Creek Formation (Chapman, 1903; Philip, 1962), the Lilydale Limestone (Gi11, 1945; 1950), and the Kilgower Member of the Tabberabbera Formation (Gi1l, 1945; 1949; Talent, 1963) all of Victoria, and the Baton River Beds (Shirley, 1938; Gi11, 1945; Wright, 1967) of New Zealand. The fauna appears to be transitionary between the Upper Yeringian (Fauna II) and the Tabberabberan (Fauna III) Brachiopod Faunas described by Strusz (1972) from Eastern Australia (see Strusz, op. cit. for Intra-Australian correlations).

Corroborating evidence is afforded by the conodont fauna (Philip and Pedder, 1967) which contains inter alia Spathognathodus sulcatus (Philip) which has been recorded from the Coopers Creek Formation (Philip, 1965), the Lilydale Limestone (Philip and Pedder, 1967c), the Waratah

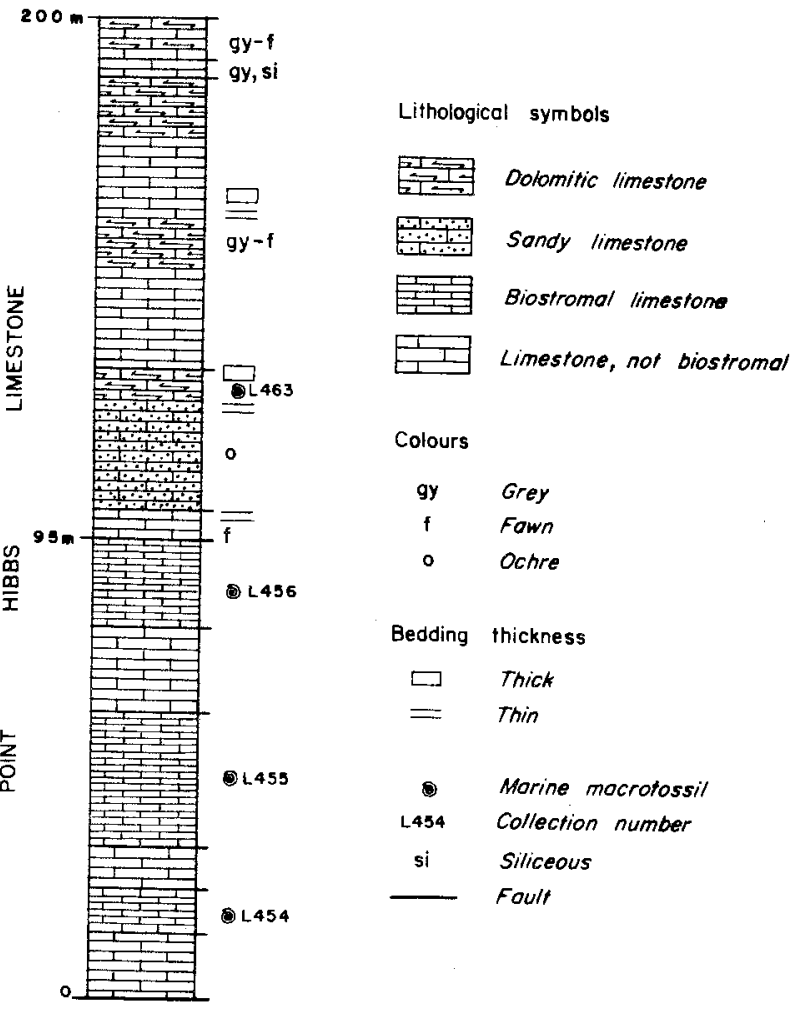

FIr. 2. - Section of the Point Hibbs Limestone, located on the northern side of Point Hibbs (measured by estimation, A.E.H. Pedder, February, 1964). 


\section{SYSTEMATIC PALAEONTOLOGY}

Systematic designations above generic rank have been omitted. The classification given by Williams and Rowell (in Moore, 1965) may be consulted for taxonomic designations above the generic level. Definitions of morphological terms are contained in the brachiopod volumes of the Treatise on Invertebrate Paleontology (Moore, op. cit.)。

$$
\text { Genus Schizophoria King, } 1850
$$

Type species. Conchylizolithus (Anomites) resupinatus Martin, 1809

$$
\text { Schizophoria sp. cf. S. provularia (Maurer, 1886) }
$$

P1. 1, figs. 9-12

Material. 18 articulated and disarticulates shells.

University of New England: 10971 - 10985. University of Tasmania: 52132, 51931, 51389 .

Description. Shells medium to large sized; unequally biconvex with brachial valve more convex than pedicle valve; cardinal extremities rounded; greatest width at midlength; hinge line straight, about half the width of the shell; dorsal valve without fold; anterior half of ventral valve with broad shallow sulcus; ventral interarea almost plane, apsacline; delthyrium high and narrow, open; dorsal interarea about half as long as ventral interarea, evenly curved, apsacline; notothyrium open, wide; external ornament of numerous fine rounded costellae, separated by narrow interspaces; costellae increase by bifurcation and intercalation; costellae crossed by few concentric growth lines.

Pedicle valve interior with long, strong, oblique dental plates, extending around the margin of the muscle area as a sharply defined ridge ( $P 1.1$, fig. 11); delthyrial cavity bounded by high dental plates; diductor scars only slightly divergent, separated by a narrow high ridge, presumably the site of attachment of the adductors; adjustor scars not observed; crural fossettes not seen.

Brachial valve interior with widely divergent brachiophores; fulcral plates define the sockets basally; sockets deep, notothyrial cavity occupied by a trilobate cardinal process with a thin triangular plate medially and two smaller rod-1ike lobes on either side; very low median ridge developed on valve floor, only extends a short distance; internal margin is crenulated by the costellae; musculature not observed.

Figured specimens. UNE 10973, $10971,10976$.

Discussion. Schizophoria sp. cf. S. provulvaria closely resembles S. provulvaria (Maurer) sensu Binnekamp (1965) from the Lower Siegenian Labanza Formation of Spain (see Renouf (1972 p. 100) for discussion). The only apparent difference is that the Tasmanian specimens have a slightly more pronounced muscle bounding ridge in the ventral valve, and the cardinal process appears to have fewer lateral lobes.

Gill (1942) described $S$. provuzvaria from early Devonian strata in Victoria, and Shirley (1938) also described this species from the Baton River Beds of New Zealand. Until these specimens can be examined or comparative material collected, the author considers it best to assign the Point Hibbs material to cf. S. provulvaria.

S. sp. cf. S. provulvaria differs from other specific descriptions of Schizophomia in the following ways: it has a different arrangement of the pedicle valve musculature from the type species; $S$. vuZvaria Schlotheim, Figured by Comte (1938), possesses much finer costellation; the figure of Schizophoria sp., Talent (196j), from the Tabberabbera Formation, Victoria, is insufficient to allow specific comparison; Schizophoria sp., 
Philip (1963), Erom the Boola Beds, bas different pedicle muscle impressions; S. schmuri Struve, figured by Anderson et al., (1969) is fiatter and has a different arrangement of the pedicle valve musculature; the Tasmanian specimens are unlike the three species and five subspecies of Schizophomia described by Struve (1965); S. muegatensis Renouf (1972) possesses a different muscle impression in the brachial valve.

The New Zealand material which Allan (1942) referred to $S$. provulvaria is now assigned to Reeftonia Allan (see Johnson \& Talent, 1968).

Genus Isorthis Kozlowski, 1929

Type species. Dalmanelza (Isorthis) szajnockai Kozlowski, 1929

Isorthis sp. cf. I. festiva Philip, 1962

P1. 1, figs. 1-4, 8 .

Material. 27 complete and incomplete shells.

UNE: 10987 - 11012. UT: 51985 - 51930.

Description. Shells medium sized, unequally biconvex; pedicle valve more convex than brachial; wider than 1ong, maximum width near mid-length; cardinal angles obtuse, rounded to subangular; pedicle beak slightly incurved; interarea slightly curved, apsacline, about half to two-thirds the width of the shell; delthyrium open, higher than wide; poorly defined fold extends from the umbo; brachial interarea short, less than half the width of the she11, analcine; brachial beak small; a relatively deep sulcus extends from the beak; anterior commissure sulcate.

Surface multicostellate; costellae increasing by bifurcation, 15-19 costellae per five $\mathrm{mm}$ at ten $\mathrm{mm}$ from beak; surface may be marked by one or two pronounced concentric growth lines; she11 substance punctate.

Pedicle valve interior with large, bluntly rounded teeth, supported by dental plates which continue anteriorly as low but distinct muscle bounding ridges; ventral muscle field elongate, extending about one-third the length of the valve, and consists of two expanding diductor scars separated by a narrow adductor ridge (P1. 1, fig. 4); adjustor musculature not observed.

Brachial valve interior with moderately deep dental sockets, bounded by low fulcral plates, anteriorly bordered by prominent, but thin bladed, inner socket ridge; bladelike brachiophores diverge forward of the midline at about $50^{\circ}$; cardinal process with long shaft and usually a bilobed myophore, tending to close the notothyrium; muscle area subquadrate, extending more than half the length of the valve, with a wide median ridge; posterior adductors slightly larger than anterior adductors, line of separation not obvious.

Figured specimens. UNE 10987 - 9, 10992, 10994.

Discussion. The Point Hibbs specimens are assigned to Isorthis and not to Reeftonia (see Boucot et al., 1967; and Johnson et al., 1968, for discussion of Reeftonia) because they possess a strong pair of anteriorly divergent dental plates; the ventral diductor scars are divided by a narrow, anteriorly prominent adductor platform; the dental sockets are defined by low fulcral plates, and the dorsal adductor scars are quadripartite and so situated on the platform as to appear to have muscle bounding ridges both laterally and antero-laterally. Isorthis festiva is known from the Boola Beds (Philip, 1962) and the Mandagery Park Formation (Savage, 1971). The type specimens of I. festiva are of smaller size than the Point Hibbs specimens. 


\section{P.G. Flood}

Genus Cymostropinia Caster, 1939

Type species. Leptaena stephani Barrande, 1848

Cymostrophia belzamgosa Talent, 1963

$$
\text { P1. 1, figs. 5-7. }
$$

Material. 63 incomplete articulate shells.

UNE: 1103-45. UT: 5135?; 51357, $-58,-63,-73,-79,-80 ; 51433,-72$;

$51580,-83 ; 51907,-21,-33,-40,-83,-86 ; 52110$;

$53302,-03$.

Description. Shells medium to large sized, wider than 1ong; angle of genticulation $\overline{80^{\circ}-90^{\circ} \text { at }}$ anterior margin, decreasing towards the rectangular cardinal extremities; maximun width along hinge line; hinge line denticulate for greater than half its width; ventral inter-area low, flat, apsacline to orthocline; pseudodeltidium slightly convex; pedicle valve weakly convex, anterior and lateral margins bent dorsally, producing a long trail; visceral disc separated from trail by an inconspicuous edge; pedicle and brachial valves closely fitting; delicate papillae on both valves.

Prominent transverse rugae on disc of both valves, and interrupted by costellae; ornamentation of costellae and fine capillae; between eight and twelve costellae per $10 \mathrm{~mm}$ measured para1lel to, and $10 \mathrm{~mm}$ from the hinge line; average of eight capillae between costellae, but increasing to fifteen or seventeen when central capillae become costellae.

Internals not observed.

Figured Specimens. UNE 11015-7.

Discussion. The type specimens of Cymostrophia beZZamgosa Talent are from the Kilgower Member of the Tabberabbera Formation. The following forms which may be closely related to C. belzarugosa have been described: Cymostrophia sp. indet., and Megastrophia (?) sp. by Philip (1962) from the Coopers Creek Formation; C. stephani by Shirley (1938) and Allan (1942) from the Baton River Beds. As nothing is known of the interiors or degree of variation of these, no meaningful comparison can be made.

\section{Genus Megastrophia Caster, 1939}

Type species. Strophomena (Strophodonta) concava Hall, 1857

Megastrophia hizzae sp. nov.

$$
\text { P1. 2, figs. 7-9. }
$$

Name. Patronym in honour of Dorothy Hill who was the first palaeontologist to suggest a Devonian age for the Point Hibbs Limestone.

Material. Four complete and ten incomplete shells.

UNE : $11046,11048-50$. UT: $51911,-25,-46,-68,-76,-89 ; 51266,51376 ; 94095$.

Diagnosis. Small to medium sized, thin shelled Megastrophia with strongly developed ornament.

Description. Shells of small to medium size, concave-convex, with the pedicle valve gently arched; cardinal extremities subrounded; hinge line straight, denticulated three- 
quarters the width of the valve; maximum width occurs posterior of midlength; ventral interarea long, flat, apsacline; delthyrium small, covered by pseudodeltidium; dorsal interarea long but narrow; ornamentation of costellae that increase by bifurcation and intercalation; she11 substance pseudopunctate.

Pedicle valve interior with well developed myophragm, anterior of the umbo; nature of the dental plates or musculature unknown.

Brachial valve interior with low cardinal process, with posteriorally disjunct lobes, also divided into two circular muscle fields inserted on a gently elevated platform, divided by a low, narrow median ridge.

Figured specimens. Holotype UT 94095; paratypes UNE 11049, 11050 .

Discussion. The pedicle valve interior impression of Megastrophia hizZae sp. nov. illustrated on P1. 2, fig. 9, shows close resemblance to the interior of $M$. iddingsi (Merrian), and the exterior ornament resembles $M$. transitans Johnson (see Johnson, 1970, pp. 120-123, P1. 26, fig. 9). There are no known species of Megastrophia from eastern Australia that show any similarity to $M$. hizzae sp. nov.

Genus Hipparionyx Vanuxem, 1842

Type species. Hipparionyx proximus Vanuxem, 1842

$$
\begin{aligned}
& \text { Hipparionyx (?) sp. } \\
& \text { P1. 2, figs. 10, } 14
\end{aligned}
$$

Material. Five incomplete and poorly preserved brachial valves.

$$
\text { UNE: } 11068-70 . \quad \text { UT: } 51945,51913 .
$$

Description. Exceptionally large shells, with rounded cardinal extremities; ornamentation of costellae that increase by bifurcation; brachial valve interior with high, divergent cardinal process lobes (P1.2, fig. 10) and median septum; no other features observed.

Figured specimens. UNE 11068-9.

Discussion. Talent (1963, p. 66) has discussed the problem of the assignment of Australian orthotetaceans to the genus Hipparionyx. The Point Hibbs specimens are so few and so poorly preserved, that they can only be questionably referred on the basis of a few morphological features to the previously described Australian species (Compare P1. 2, fig. 14, with Talent, 1963, P1. 31, fig. A2).

Species of Hipparionyx have been recorded by Shirley (1938) from the Baton River Beds, by Gil1 (1942, 1949) from sediments at Sandy Creek, and by Talent (1963) from the Tabberabbera Formation.

Genus Chonetes Fisher de Waldheim, 1830

Type species. Terebratulites sarcinulatus von Schlotheim, 1820

"Chonetes" sp.

P1. 2, figs. 5-6

Material. Three incomplete pedicle valves.

UNE: $\quad 11071-3$. 
Description. Pedicle valve is medium to large sized, moderately convex; hinge line straight, slightly less than maximum width; ornament consisting of low rounded radiating costae, originating in the umbonal and hinge line region; costae increase by bifurcation; spines or concentric growth lines not observed.

Figured specimens. UNE 11071-2.

Discussion. The Point Hibbs material is referred to as "Chonetes" because many of the Victorian and southern New South Wales chonetid species are now referred either to Parachonetes or to Protochonetes. A more definite assignment would require material illustrating the internal structures of both valves.

"Chonetes" sp. may be closely related to Chonetes robusta Chapman (1903) which has been recorded from the Lilydale area (Gill, 1945), and from the Baton River Beds (Gill, 1952). Gill's illustrations are too poor for a detailed comparison.

"Chonetes" sp. has similar arrangement of costae, but is of smaller size than Chonetes baragwanathi Gill, described by Talent (1963) from the Tabberabbera Formation. Genus Machaeraria Cooper, 1955

Type species. RhynchonelZa formosa Hall, 1857

Machaeraria sp. cf. M. formosa (Ha11)

P1. 3, figs. 5-6, 9-12.

Material. 51 complete shells.

UNE : $11077-11122$. UT: $51337,-73,-74,-77,-95 ; 51407,-12,-28$; $51926,-42,-55,-64 ; 52100,-04,-08,-67$.

Description. Shells small to medium sized, inequivalved, subpentagonal biconvex; wider than long; greatest width and height forward of midlength; cardinal extremities rounded; hinge line curved and small; ventral valve moderately convex; suberect beak; small submesothyrid foramen; delthyrium medium sized, restricted by narrow disjunct deltidial plates; sulcus wide and deep bearing three plications, increasing by intercalation; dorsal valve strongly convex; broad umbo; small uncurved beak; fold wide and low, bearing four plications, increasing by bifurcation; anterior commissure strongly uniplicate; sinus strongly trapezoidal; surface ornament of 12-24 strong angular plications; number of plications on lateral slopes constant for each specimen; fine growth lines visible on well preserved specimens.

Pedicle valve interior with short, narrow dental plates supporting slender teeth, with small fosettes which articulate with the outer edge of the inner socket ridges; musculature not observed.

Brachial valve interior with divided hinge plate; outer plates broad and triangular, serve as crural bases; crura long and curved, free end bluntly pointed, conjunct posteriorly, forming a narrow elongate norothyrial cavity, occupied by a long thin cardinal process; musculature not impressed.

Figured specimens. UNE 11077, 11088-89.

Discussion. The Point Hibbs specimens resemble $M$. formosa (Hall) in external morphology, but definite assignment is deferred until comparative material can be obtained. The Point Hibbs specimens consistently display four plications on the fold and three in the sulcus. This, together with the angular nature of the plications, readily distinguishes them from $M$. catombatensis Strusz (1970), $M$. (?) sp. Talent (1963), and M. cf. formosa described by Savage (1971). 
Genus Uncinulus Bay1e, 1878

Type species. Hemithyris subwizsoni d'Orbigny, 1850

$$
\begin{gathered}
\text { Uncinulus (?) globosus Ta1ent, } 1956 \\
\text { P1. 2, figs. 1-4. }
\end{gathered}
$$

Material. 23 complete shells.

UNE: 11148 - 69. UT: 51433; 51984.

Description. Shells small, unequally biconvex, subpentagonal to rounded in outline; lateral margins rounded; postero-lateral margin slightly concave and meeting in an acutely angular beak; beak slightly incurved to suberect; foramen minute; fold and sulcus begin anterior of mid-length; fold bears a medium depression; sulcus with an enlarged costae which appears as a median fold; anterior commissure strongly uniplicate; external ornament of 13 to 27 costae, commonly bifurcating near the anterior margin; sulcus bearing three plications; fold bearing four plications.

Pedicle valve interior with posteriorly located dental plates; teeth, musculature, median ridge not seen.

Brachial valve interior with very shallow septalium, supported posteriorly by a high, narrow median septum; median septum extends up to one third the length of the valve; hinge plate broad, thin and anteriorly divided; dental sockets narrow; musculature not distinguishable; cardinal process not observed.

Figured specimens. UNE $11154-55$.

Discussion. The subtlety of the differences between the related genera of the Rhynchonellacea, added to the fact that the internal structure of Uncinulus (?) globosus Talent is not known, makes a definite generic assignment of this species questionable.

It was impossible to determine the true nature of the internal structure of the Tasmanian specimens because their very small size renders serial sectioning techniques useless and they are assigned to $U$. (?) globosus solely on the basis of their similar external morphology. U. (?) globosus is known from the Coopers Creek Formation (Talent, 1956)

\section{Genus Hebeotoechia Havli̊̌ek, 1959}

Type species. Terebratuza hebe Barrande, 1848

$$
\begin{gathered}
\text { Hebeotoechia hibbensis sp. nov. } \\
\text { P1. 3, figs. 1-4, 7-8. }
\end{gathered}
$$

Name derivation. Point Hibbs, a headland on the western coast of Tasmania, where the species is known to occur.

Material. 50 complete and incomplete articulated shells, and six incomplete disarticulated shelis.

$$
\text { UNE: } 11123-11145 . \quad \text { UT: } \begin{aligned}
& 51360,-61,-66,-67 ; 51371,-75,-78,-81,-83, \\
& -84,-86,-90 ; 51402,-3,5,-16,-21,-26,-27, \\
& -65,-66 ; 51582 ; 51959,-60,-74,-80,-91 ; \\
& 52107,-28,-33,-56 ; 53300 ; ? 6908 ; 5336 ?
\end{aligned}
$$


Diagnosis. Medium to exceptionally large sized Hebeotoechia, with 28 to 52 costae, increasing by bifurcation; fold and sulcus almost imperceptible; sulcus with five to seven costae; ventral muscle field circular, shallowly impressed; dental plates almost obsolete; teeth large; septalium supported by a median septum and filled out in its posterior part with callus projecting above the hinge plate as a bilobed process.

Description. Shells medium to large sized, biconvex, rounded to subpentagonal in outline; suberect pedicle beak; minute foramen; fold and sulcus almost imperceptible, developed slightly posterior of mid-length; anterior commissure strongly uniplicate; external ornament of 28 to 52 low, slightly rounded bifurcating costae, separated by narrow furrows; sulcus bears five to seven costae; longitudinally grooved costae near the commissure.

Pedicle valve interior with almost obsolete concave dental plates, supporting strong, blunt teeth; small circular muscle field shallowly impressed; pedicle cavity sma 11 .

Brachial valve interior with deep septalium, supported posteriorly by a high, narrow median septum; septalium filled out in its posterior part with callus forming the cardinal process; cardinal process bilobed and bears a bordering ridge; always a groove between the two lobes of callus; hinge plate thin and bearing short dental sockets bounded by the cardinal margin and the inner socket ridges; median septum extending about one-third the length of the valve; musculature not distinguishable.

Figured specimens. Holotype UT 51416; paratypes UNE 11123; UT 51421.

Discussion. The Point Hibbs specimens are assigned to Hebeotoechia Hav1ícek and not to Plethorhyncha Ha11 and Clarke on the basis of the internal structure of the brachial valve. Havlícek (1961, p. 119) remarks that the septalium of Hebeotoechia bears a bilobed cardinal process that always has a groove between the two lobes, whereas Plethorhyncha has a completely callus filled septalium.

Hebeotoechia hibbensis sp. nov. differs in external form from the four species, $H$. hebe (Barrande), H. omatrix Havlicek, H. compta (Barrande), and $H$. nitiduZa (Barrande) described by Havlíčk in 1961. It also differs in external shape from H. cantabrica Binnekamp (1965), and from H. cf. H. hebe described by Lenz (1970).

Philip (1962, p. 216) referred to the presence of large rhynchonellids in the Lower Devonian of Victoria and suggested that the Lilydale form identified as Eatonia (Eatonia) affin. bithynica Gil1 (1952) (= ? Uncinulus strickiandi Sowerby, Chapman 1903, p. 78) could represent a species of Plethorhyncha. E. bithynida has been recorded by Shirley (1938) from the Baton River Beds. Talent (1963, p. 76) also commented on the presence of large cuboidal rhynchonellids in the Lower Devonian of Victoria. He referred specimens from Lilydale and from Tabberabbera to Sphaerirhynchia Cooper and Muir Wood, but qualified this assignment by suggesting that the forms could be assignable to Hebeotoechia. Unfortunately, the internal structures, of the victorian and New Zealand rhynchonellids are poorly known and so a detailed comparison with the Tasmanian material is not meaningful.

Genus Atrypa Dalman, 1828

Type species. Anomia reticularis Linnaeus, 1758 


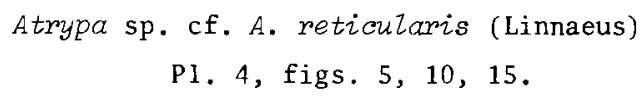

Material. 11 complete she11s.

UNE : $11179-87 . \quad$ UT: $51928 ; 53118$.

Description. Shells medium to large sized; unequally biconvex, brachial valve more convex than pedicle valve; cardinal extremities subrounded; hinge line straight; maximum width near or posterior of midlength; dorsal fold and ventral sulcus present towards anterior margin; commissure gently uniplicate; pedicle beak pointed, suberect to slightly incurved; brachial beak strongly incurved, not exposed externally; interarea or delthyrium not observable.

Ornament of well developed, rounded radial costae, numbering about ten per $10 \mathrm{~mm}$ at $20 \mathrm{~mm}$ from the beak; costae separated by narrow U-shaped interspaces; costae commonly increase by bifurcation on the pedicle valve, and by intercalation on the brachial valve; costae increase in size anteriorly; concentric growth lines only moderately defined posteriorly.

Pedicle valve interior with large blunt teeth, joined to the lateral margin of the she11 and supported by dental plates which are sometimes obscured by secondary shell deposition; bounding the teeth posterolaterally are two well developed secondary dental sockets; the dorsal end of the tooth is notched by a shallow groove; musculature deeply impressed.

Brachial valve interior with what appears to be a small cardinal process; deep dental sockets are defined between the postero-lateral edge of the valve and the prominent, strongly curved crural plates; crural lobes recurve ventrally and then laterally to cover the inner edge of the posterior part of the sockets; the sprialium consisting of about 13 turns; apices of the spiralia are close to the inner surface of the valve; median septum absent; musculature not observed.

Figured specimens. UNE 11179, 11182 .

Discussion. The species name cf. A reticularis is generally used for forms close to the type species of Atrypa, because the original description, and Alexander's (1949) revision of the type species allow a wide range of forms to be placed in this species. Atrypids of this type constitute an exceedingly common and widespread group, many forms of which have names that have been erected with little or no regard to comparable forms.

Numerous Australian atrypids have been referred to as Atrypa reticularis. Gill (1950) described Atrypa reticularis from Lilydale; Chapman (1903) described A. reticularis var decurrens from the Coopers Creek Formation and Boola Beds; Philip (1962) described $A$. sp. cf. A. reticularis from the Boola Beds; Talent (1963) described $A$. cf. reticularis from the Tabberabbera Formation; Mitche11 and Dun (1920) recorded A. reticularis from several localities in southern New South Wales; and Savage (1970) recorded a new subspecies $A$. reticularis inversa from the Mandagery Park Formation.

Until a comprehensive study is made of all Australian atrypids and a comparison made with overseas species, it would be unreasonable to positively identify the Point Hibbs material as the species $A$. reticularis as there is an enormous range of variation in shape and external ornament within that species (see Atrypa reticularis figured by Bowen (1967, P1. 5, figs. 28-40), A. "reticularis" figured by Boucot and Johnson (1968, P1. 3, figs. 30-49) or A. "reticularis" figured by Anderson et. al., (1969, P1. 7, figs. 6-19). 
Genus MeristelZa Ha11, 1860

Type species. Atrypa Zaivis Vanuxem, 1842

\author{
Meristella sp. \\ P1. 2, figs. 11-13
}

Material. One complete and eight incomplete shells.

UNE: $11170-2 ; 11174 ; 11177-8$.

Description. Shells medium sized, sub-equally biconvex, subcircular in out line, elliptical in profile; lateral slopes from the umbo to mid-length almost straight; length greater than width; maximum width occurring slightly posterior of midlength; hinge line short with rounded cardinal extremities; pedicle foramen small, suberect beak; sulcus and fold absent; ornament of cencentric growth lines crossed by closely crowded radial lines.

Pedicle valve interior with long, strongly divergent dental plates; teeth not observed; median septum absent; musculature indistinct.

Brachial valve interior with long, high median septum extending up to midlength; median septum united to the well defined dental sockets to form a shallow cruralium; spiralium and jugum not seen; musculature indistinct.

Figured specimen. UNE 11170.

Discussion The Point Hibbs specimens are so few and so poorly preserved that a precise specific assignment is not possible. Meristella has been recorded from the Bell Shale (Gil1, 1950), Lilydale (Gill, 1950b), Boola Beds (Philip, 1962), and from the Mandagery Park Formation (Savage, 1971).

Genus Athyris McCoy, 1844

Type species. Terebratula concentrica von Buch, 1834

$$
\text { Athyris (?) sp. }
$$

Material. Three poorly preserved, incomplete shells.

UNE: $11173,-5,-6$.

Description. Shells small sized, subequally biconvex, subcircular in outline; maximum width occurs close to midlength; cardinal angles obtuse and well rounded; dorsal fold and ventral sulcus slightly developed; pedicle beak slightly incurved; no other features observab1e.

Pedicle valve interior with short dental plates, gently concave medially; teeth not observed; median septum absent; musculature indistinct.

Brachial valve interior with well defined dental sockets; hinge plate short, perforated posteriorly, conjunct anteriorly; crura short, widely divergent; median septum absent; no other features observable.

Discussion. The degree of recrystallisation and scarcity of specimens hinders precise definition of the Point Hibbs material. The general shape, divergent dental plates, perforate hinge plate, and absence of a median septum are suggestive of Athyris, to which the material is tentatively assigned. 
Chatterton (1969) has shown that the internal structure of Buchanathyris waratahensis Talent (1956) agrees with that of Athyris. It would appear that the validity of the genus Buchanathymis Talent, 1956, is questionable and that forms from the Tabberabbera Formation, described by Talent (1963) could be just as well assigned to Athyris. The Point Hibbs specimens show resemblance to $B$. westoni (?), described by Talent (1963) from the Kilgower Member, but the preservation of the material in either collection, is insufficient to allow a more precise comparison.

The Point Hibbs specimens are relatively flatter than the figured types of $B$. westoni Talent (1956) from the Buchan Caves Limestone.

Genus Cyrtina Davidson, 1858

Type species. Calceola heteroclita Defrance, 1828

\section{Cyrtina heteroclita (Defrance)}

(P1. 4, figs. 1, 6, 11

1962 Cyrtina cf. homiztonensis, Banks in Spry and Banks, p. 185.

1967 Cyrtina cf. homiztonensis, Banks in Talent and Banks, p. 159.

Material. 27 complete, or almost complete shells.

UNE: $11188-11208$. UT: $51924,-31,-47,-70,-77,-90,-93$.

Description. Shells medium sized, strongly unequally biconvex; the brachial valve weakly convex, uniform convexity; pedicle valve deep and hemipyramidal, in some deformed; pedicle beak pointed, erect to slightly curved at the posterior tip; ventral interarea high, triangular, planar to moderately concave, apsacline, divided by a long narrow delthyrium; subhypothyridid foramen present at apex of delthyrium; brachial interarea narrow and inconspicuous; cardinal angles acute $\left(60^{\circ}-85^{\circ}\right)$; maximum width at or slight$1 y$ anterior of the hinge line; fold and sulcus prominent, extending from the posterior margin to the parasulcate anterior commissure; fold commonly flattened along its crest; lateral margins convex, bearing three to four rather strong rounded plications on either side of fold and sulcus; micro-ornament consists of irregularly spaced, concentric growth lemellae; shell substance finely punctate.

Pedicle valve interior with convergent dental plates, paralleling the inner edge of the delthyrium and uniting just above the floor of the valve to form a prominent spondylium, supported by a high median septum which intrudes the spondylial cavity as a trichorhinum; teeth of moderate size; muscle scars not observable.

Brachial interior with deep triangular dental sockets, supported by anteriorly divergent crural bases; crural plates absent; spiralia large, occupying most of the shell interior, cach consisting of five to six volutions; median septum, cardinal process or musculature not observable.

Figured specimens. UNE 11189; UT 51393.

Discussion. Specimens from Point Hibbs are similar to C.h. gregale Talent (1963) in that they have similar numbers of plicae, and a deep pedicle valve that at times is twisted. Unfortunately, the originals of $C$. h. gregale consists of moulds which are distorted thus making detailed comparison with the Point Hibbs material difficult. The illustrations of specimens from the Baton River Beds of New Zealand which Shirley (1938) referred to as $C$. heteroclita are inadequate to allow any comparison with the Point Hibbs material. 
An examination of the type specimens of C. wezlingtonensis (Dun, 1904) and silicified topotypic material collected by Dr. D.L. Strusz from the Garra Formation, reveals that the Point Hibbs species can be distinguished by its smaller cardinal angle, flatter fold, less convex brachial valve, relatively larger size, and its "rugged" appearance.

Genus Acrospinifer Helmbrecht and Wedekind, 1923

Type species. Spirifer primaevus Steininger, 1853, by designation of Wedeking, 1926, p. 202 .

$$
\begin{aligned}
& \text { Acrospipifer banksi sp. nov. } \\
& \text { P1. 4, fig. 2-4, 7-9, 12-14. }
\end{aligned}
$$

1962 Acrospirifer, Banks in Spry and Banks, p. 185.

1962 Acrospirifer, Banks in Talent and Banks, p. 159.

Name derivation, Patronym in honour of Maxwell Banks of the University of Tasmanian who collected many of the brachiopod specimens.

Material. 85 complete and incomplete she1ls.

$$
\begin{array}{ll}
\text { UNE : } 11209-11214, \mathrm{UT}: & 51306,-82,-94,-97,-99 ; 51400,-01,-17,-19 ; \\
& 51579,51910,-2,-17,-19,-29,-32 ; 51942,-44, \\
& -49,-50,-51,-62,-73,-75,-87,-92,-93 ; \\
& 52124 ; 57906 ; 94096 .
\end{array}
$$

Diagnosis. Small to medium sized Acrospirifer with few (three to eight, commonly three to six) plications; plications broad and low showing a marked size increase anteriorly and marked size decrease postero-laterally; hinge line straight; cardinal extremities acute to obtuse $\left(80^{\circ}-105^{\circ}\right)$, evenly rounded; pedicle interarea long, curved, and bearing longitudinal and transverse striations; triangular delthyrium open and bordered by small deltidial plates; micro-ornament of distinct low concentric growth lamellae crossing the plications, and each bearing closely spaced tear-shaped granules.

Descriptions. Shell of small to medium size, unequally biconvex, wider than long; pedicle valve slightly more convex than brachial valve; hinge line long and straight, the place of maximum width; cardinal extremities acute to obtuse $\left(80^{\circ}-105^{\circ}\right)$ and subrounded; pedicle beak hooked at the posterior end; pedicle interarea long, low, triangular, slightly curved and apsacline, longitudinally and transversely striated; delthyrium triangular, open, and bordered by small deltidial plates (Pl. 4, fig. 9); brachial beak slightly incurved over the hinge area.

External ornament of three to eight well defined broad, rounded plications on each lateral slope; progressively narrower than adjoining plications; well developed noncostatebrachial fold and pedicle sulcus, fold wider than high; micro-ornament of distinct low concentric lemellae crossing the plications of each lamellae bearing a row of closely spaced tear shaped granules.

Pedicle valve interior with long, well defined dental plates, widely divergent basally, commonly almost obsolescent by thick developments of secondary shell material in the umbonal cavity; teeth strong and suboval; inner surface strongly crenulated by the impression of the plications; musculature indistinct.

Brachial valve interior with short, deep dental sockets, divergent anterolaterally; socket plates thickened by the attachment of plate-like crural bases, but crural plates absent; inner surface moderately crenulated by the impression of the plications; musculature indistinct; cardinal process not observed; nature of spiralium unknown. 
Figured specimens. Holotype UT94096; Paratypes UNE $11210-13$ and UT 51400 .

Discussion. A. banksi appears to be closely related to the large pauciplicate forms with deep U-shaped interspaces that are common in the Siegenian strata of the European sequence (Drot, 1964; Vandercammen, 1963), and to forms described as A. aff. murchisoni (Castelneau) from the Trematospira Zone of Nevada (Johnson, 1970, P1. 56, figs. 5-13) .

A. banksi differs from A. Zilydalensis (Chapman, 1913) in that the latter possesses a feebly plicated ventral sulcus; a longitudinally striated dorsal fold; and eight to ten plications on each side of the fold and sulcus. Shirley's (1938) illustrations of Acrospirifer arduennensis from the Baton River Beds are too poor to allow comparison with the Point Hibbs specimens.

\section{ACKNOWLEDGEMENTS}

I am indebted to the following: M.R. Banks who loaned material from the fossil collection of the University of Tasmania; and G.M. Philip and A.E.H. Pedder who collected the University of New England material during February, 1964.

\section{REFERENCES}

Alexander, F.E.S., 1949: Revision of the brachiopod species Anomia reticularis Linnaeus genolectotype of Atrypa Delman. Geol. Soc. London Quat. Jour., 104, 207-220.

Allan, R.S., 1942: The origin of the Lower Devonian fauna of Reefton, New Zealand. Trans. Proc. R. Soc. N.2., 72, 144-147.

, 1947: A revision of the Brachiopoda of the Lower Devonian Strata of Reefton, New Zealand. J. Paleont., 21, (5), 436-452.

Amsden, T., 1958: Haragan articulate brachiopods, Pt. II (and) Supplement to the Henryhouse brachiopods, Pt. III of stratigraphy and paleontology of the Hunton Group in the Arbuckle Mountain region. OkZahoma Geol. Survey BuzZ., 78, 9-158.

Anderson, M.N., Boucot, A.J., \& Johnston, J.G., 1969:Eifelian brachiopods from Padaukpin, Northern Shan States, Burma. BulZ. Br. Mus. Nat. Hist. (Geol.), 18 (4), 1-163.

Banks, M.R., Ahmad, ‥, \& Ford, R.J., 1960 : Geology of Point Hibbs. Univ. of Tasmania, Geol. Dept., one inch series - 3375 .

Barrande, J., 1848: Ueber die Brachiopoden der silurischen Schichten von Bohmen, II, Teil. Natumw. Abh. (Ha idingers) II. Wien.

Bayle, E., 1878: Explication de la carte geologique de France $\underline{4}$ (1). AtZas Fossizes principaux des terrains.

Binnekamp, J.G:, 1965: Lower Devonian Brachiopods and stratigraphy of North Palencia (Cantabrian Mountains, Spain). Leid. geol. Meded., 33, 1-62.

Boucot, A.J., E Johnson, J.G., 1968: Brachiopods of the Bois Blanc Formation in New York. Spec. pop. U.S. geol. Surv., 584-B, 1-27.

, Johnson, J.G., छ Talent, J.A., 1967: Lower and Midd1e Devonian faunal provinces based on Brachiopoda. Intemat. Symposium on the Devonian System, Ca1gary, Alberta 1967, 2, 1239-1254. Alberta Soc. Petrol. Geol., Calgary.

, 1967b: Early Devonian brachiopods zoogeography. Geol. Soc. 


\section{P.G. Flood}

Bowen, Z.P., 1967: Brachiopods of the Keyser Limestone (Silurian-Devonian) of Maryland and adjacent areas. Mem. geol. Soc. Amer. 102, 1-103.

Carls, P., 1969: Die Conodonten des tieferen Unter-Devons der Gyadarrama (MittelSpanien) und die Stellung des Grenzbereiches Lochkovium/Pragium nach der rheinschen Gliederung. Senck. leth., 50 (4), 303-355.

, \& Gandl, J., 1969: Stratigraphie und Conodonten des Unter-Devons der Ost1ichen Iberischen Ketten (N.E.-Spanien). N. Jb. Geol. Palaont. Abh., 132 (2), 155-218.

Caster, K.E., 1939: A Devonian fauna from Columbia. BuZZ. Amer. Paleont., 24.

Chatterton, B.D.E., 1969: Some aspects of the paleontology, palaeoecology and biostratigraphy of the limestones of the Murmmbidgee Group at Taemas near Yass, New South Wales. Unpub. Ph.D. Thesis, Australian Nationa1 University.

Chapman, F., 1913: New or 1ittle-known Victorian Fossils in the National Museum, Melbourne. Pt. 16, Some Silurian Brachiopoda. Proc. Roy. Soc. Vict., 26, 99-113.

Comte,, P., 1938: Brachiopodes devoniens des gisements de Ferrones (Austuries) et de Sabero (Leon). A. Paleont., Paris, 27, (1-50), 41-88, p1. I-IV.

Cooper, G.A., 1955: New genera of Middle Paleozoic Brachiopoda. J. Paleont., $\underline{29}(1), 45-63$, p1s. 11-14.

Da11, W.H., 1877: Index to the names which have been applied to the subdivisions of the class Brachiopoda. BulZ. U.S. Nat. Mus., $\underline{8}, 1-88$.

Dalman, J.W., 1828: Uppstallning ach Beskrifning af de i Sverige Funne Terebratuliter. Kongl. Svenska Vetenskapsalad Handl., 1827, 85-155.

Davidson, T., 1858: A monograph of the British fossil Brachiopoda (Permian), 2 (4), 1-51.

Drot, J., 1964: Rhynchonelloidea et Spiriferoidea Siluro-Dévoniens du Maroc PreSaharien. Notes Mem. Serv. Mines Carte géol. Maroc., 178, 1-286.

Druce, E.C., 1971: Conodonts from the Garra Formation (Lower Devonian), New South Wales. Aust. Bur. Min. Res. Geol. and Geophys. Bull., 116, 29-52.

Dun, W.S., 1904: Notes on some New Species of Palaeozoic Brachiopoda. Rec. Geol. Surv. N.S.W., 7, 320-323.

Fisher de Waldheim, 1830: Oryctographie du Gouvernment de Moscow. Moscow.

Gil1, E.D., 1942: The Thickness and Age of the Type Yeringian Strata, Lilydale, Victoria. Proc. Roy Soc. Vict., 54, 245-255.

, 1949: Devonian fossi1s from Sandy's Creek, Gippsland, Victoria. Mem. Nat. Mus. Melb., 16, 91-115.

, 1950: Preliminary account of the Palaeontology and Palaeoecology of the Eldon Group Formations of the Zeehan Area, Tasmania. Pap. Proc. Roy Soc. Tasm. (1949), 231-258.

, 1950b: Revision of McCoy's 'Prodromus' Types from the Lilydale and Ki11ara Districts of Victoria. Proc. Roy Soc. Vict, 63, 31-39.

Hall, J., 1857: Description of the Organic Remains of the Lower Division of the New York System. PaZeontology of New York, Geol. Surv., New York, 1, 1-338. 
, 1860: Descriptions of new species of fossils from the Silurian rocks of Nova Scotia. Canadian Naturalist Geologist, 5, 144-159.

, $\xi_{\text {Clarke, J.M. }}$ 1893: An introduction to the study of the genera of Paleozoic Brachiopoda. Paleontology of New York, 8 (Pt. 2), 1-317.

Havlî́cek, V., 1959: Spiriferidae v \&eskłm siluru a devonu (Brachiopoda) Rospr. Ustred. Ust. geol. Svazek., 25, 1-275.

, 1961: Rhynchonellidea des böhischen älteren Paläozoikums (Brachiopoda). Rospr. Ustred Ust. geoz. Svazek., 27, 1-211.

, 1967: Brachiopoda of the Suborder Strophomenidina in Czechoslavakia. Rospr. Ustrea. Ust. geol. Svazek., 33, 1-235.

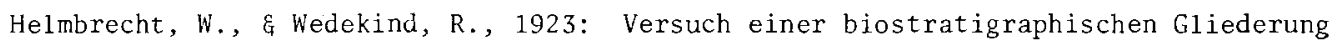
der Siegener Schichten auf Grund von Rensselarien und Spiriferen. Gluckauf, Berg. - Und Huttenmannische Zeitschrift, Jahrg, 59 (41), 949-953.

Hi11, D., 1942: Some Tasmanian Palaeozoic Corals. Pap. Proc. Roy. Soc. Tasm., (1941), 3-12. , 1967: Devonian of Eastern Australia. Intern. Devonian Symp., 1, 613-630.

Jil1s, L., 1914: Geological Reconnaissance of the Country Between Cape Sore11 and Point Hibbs. Tasm. Dept. Mines Geol. Surv. Bulz., 18, 1-23.

Jell, J.S., \& Hill, D., 1970: The Devonian Coral Fauna of the Point Hibbs Limestone, Tasmania. Pap. Proc. Roy Soc. Tasm., 104, 1-16.

Johnson, J.G., 1970: Great Basin Lower Devonian Brachiopoda. Mem. geol. Soe. Amer., $\underline{121}, 1-421$.

, Boucot, A.J., E Murphy, M.^.. 1ก67: Lower Devonian faunal succession in Central ivevada. Intern. Devonian Symp., 2, 679-691.

, E Talent, J.A., 1968: Cortezorthinae a new subfamily of Siluro-Devonian dalmanellid brachiopods. Palaeontology, 10 (1), 142-170.

Klapper, G., 1969: Lower Devonian conodont sequence, Royal Creek, Yukon Territory, and Devon Island, Canada. J. Paleont., 43 (1), 1-27.

Kozlowski, R., 1929: Les brachiopodes Gotlandiens de la Podolie Polonaise. Palaeont. pol. 1, 1-254.

King, W., 1850: A monograph of the Permian fossils of England. PaZaeontograph. Soc. Mon., 3, 1-258.

'Lenz, A.C., 1966: Upper Silurian and Lower Devonian paleontology and correlations, Royal Creek, Yukon Territory. A preliminary report. Buzz. Can. Petroz. Geoz., 14 (4), 604-612.

, 1967: Upper Silurian and Lower Devonian Biostratigraphy, Royal Creek, Yukon Territory, Canada. Intern. Devonian Symp., 2, 587-599.

, 1970: Late Silurian Brachiopods of Prongs Creek, Northern Yukon. J. Paleont., $44(3), 480-500$.

Linnaeus, C., 1758: Systema Naturae. (10th ed.). 1. Holmiae.

Martin, W., 1809: Petrificata derbiensia, or figures and descriptions of petrifications collected in Derbyshire. 1-28 (Wigan). 


\section{P.G. Flood}

Miller, S.A., 1889: Northern Americon geology and paleontology. Cincinnati, 1-664.

Mitchell, J., \& Dun, W.S., 1920: The Atrypidae of New South Wales, with reference to those recorded from other states of Australia. Proc. Linn. Soc. N.S.W., 45, $266-276$.

Moore, R.C. (Ed), 1965: Treatise on Invertebrate Paleontology. Part H, Brachiopoda. Univ. Kansas, Lawrence. 2 vols.

McCoy, F., 1844: A synopsis of the characters of the carboniferous limestone fossizs of Ireland. Dub1in, 1-207.

Oeh1ert, D.P., 1901. Fossiles Dévoniens de Santa Lucia. Buzz. Soc. géoz. Fr., $1,233-250$.

Orbigny, A.D., 1850: Prödrome de Paléontologique stratigraphique universelze. 1 (for 1849), Paris, 1-393.

Pedder, A.E.H., 1966: Devonian Tetracoral Faunas. Unpub. Ph.D. Thesis, University of New England.

Philip, G.M., 1962: The palaeontology and stratigraphy of the Siluro-Devonian sediments of the Tyers area, Gippsland, Victoria. Proc. Roy Soc. Vict., 75, 123-246.

, 1965: Lower Devonian conodonts from the Tyers area, Gippsland, Victoria. Ibid., 79 (1), 95-117.

G Jackson, J.H., 1970: The sequence of lower and middle Devonian conodont faunas in Eastern Australia. Proc. 3rd Intem. Symp. SiZurian-Devonian Boundary. Leningrad, 1968.

G Pedder, A.E.H., 1967: Stratigraphical correlation of the principal Devonian limestone sequences of Eastern Australia. Intem. Devonian Symp., 2, 1025-1041.

, 1967b: A correlation of some Devonian 1 imestones of New South Wales and Victoria. Geol. Mag., 104, 232-239.

, 1967c: The age of the Lilydale Limestone (Devonian), Victoria. J. Paleont., 41 (3), 795-798.

Pickett, J.W., 1972: Correlation of the Middle Devonian Formations of Australia. J. geol. Soc. Aust., 18 (4), 457-466.

Pitrat, C.W., 1965: Spiriferidina, in Moore, R.C., (ed.), Treatise on Invertebrate Paleontology. Part H, Brachiopoda. Univ. Kansas, Lawrence.

Renouf, J.T., 1972: Brachiopods from the Gres a Orthis monnieri Formation of Northwestern France and thier significance in Gedinnian/Siegenian stratigraphy of Europe. PaZaeontographica Abt. A, 139 (4-6), 89-133.

Savage, N.M., 1969: The Geology of the Manildra District, New South wales. J. Proc. Roy SoC. N.S.W., $101(3,4), 159-178$.

, 1969b: New Spiriferid brachiopods from the Lower Devonian of New South Wales. Paleontology, 12 (3), 472-487.

, 1970: New Atrypid Brachiopods from the Lower Devonian of New South Wales. J. Paleont., 44 (4), 655-668.

, 1971: Brachiopods from the Lower Devonian Mandagery Park Formation, New South Wales, Palaeontology, 14 (3), 387-422. 
, 1973: Lower Devonian Conodonts from New South Wales. PaZaeontology, 16 (2), $307-333$.

, 1973b: Lower Devonian biostratigraphic correlation in Eastern Australia and Western North America. Lethaia., 5, 341-348.

Shirley, J., 1938: The Fauna of the Baton River Beds (Devonian), New Zealand. Quart. J. geot. Soc. London, 94, 459-506.

Spry, A., \& Banks, M.R., (eds), 1962. The Geology of Tasmania. J. geoz. Soc. Aust., 9, 2, 107-362.

Steininger, J., 1853: Geognostische Beschreiburg der Eifez. Tries, 1-143.

Strusz, D.L., 1970: A new species of rhynchonellid brachiopod from the Devonian of New South Wales. Bur. Min. Resour. Aust. Bulz., 108, 304-326.

, 1972: Correlation of the Lower Devonian Formations of Australia. J. geol. Soc. Aust., 18 (4), 427-456.

Struve, W., 1965: Schizophoria striatula and Schizophoria excisa in ihrer ursprung1ichen Bedentung. Senck. Zeth., 46, 193-215.

Talent, J.A., 1956: Siluro-Devonian Brachiopods from Marble Creek, Thompson River, Victoria. Proc. Roy Soc. Vict., 68, 73-84.

, 1963: The Devonian of the Mitche11 and Wentworth Rivers. Geol. Surv. Vict. Mem., 24, 1-118.

, E Banks, M.R., 1967: Devonian of Victoria and Tasmania. Intern. Devonian Symp., 2, 147-163.

Vandercammen, A., 1963: Spiriferidae du Devonian de la Belgique. Bruscelzea Inst. Roy. Sai. Nat. de Belgique Mem. 150, 1-181.

Vanuxem, L., 1842: Geology of New York, Pt. 3, comprising the survey of the third geological district. Natural History of New York. Albany, 1-306.

Wedekind, R., 1926: Die devonische Formation in Saloman, Wilhelm. Grundzug der Geologie, 2 Stuttgart, E. Schweizer-bast'sche, 194-226.

Neller, S., 1903: The Paleozoic faunas. New Jersey Geol. Sumey, Rep. on Paleontology, 3, $1-462$.

Williams, A., 1953: North American and European stropheodontids, their morphology and systematics. Mem. geol. Soc. Amer., 56, 1-67.

1965: Suborder Strophomenidina in Moore, R.C., ed., Treatise on Invertebrate Paleontology. Part, H, Brachiopoda. Univ. Kansas, Lawrence.

Wright, A.J., 1967: Devonian of New Zealand. Intern. Devonian Symp., 1, 631-636. 
PLATE 1

All specimens were whitened with ammonium chloride. Al1 figures $\times 2$ except $5-7 \times 1 \frac{1}{2}$ and $4,8 \times 4$.

Figs 1 - 4, 8. Isorthis sp. cf. I. festiva Philip, 1962. 1-3, Posterior, anterior, and dorsa1 views, UNE F10987 - 9 respectively. 4, Cast of pedicle valve interior, UNE F10992. 8, Brachial valve interior, UNE F10994.

Figs 5 - 6. Cymostrophia belZarugosa Talent, 1963. Ventral, dorsal, and ventral views, UNE F11015, 11017 and 11016.

Figs 9 - 12. Schizophoria sp. cf. S. provularia (Maurer, 1886).9 - 10, Cast of ventral valve interior, and anterior, UNE F10971. II, Interior of pedicle valve, UNE 10976. 12, Ventral, view, UNE F10973.

\section{PLATE 2}

A11 specimens were whitened with ammonium chloride.

All figures $\times 3$ except 10 and $14 \times 2$.

Figs 1 - 4. uncinulus (?) globosus Talent, 1956. Ventral, dorsal, ventral and anterior views of UNE F 11154, 11154, 11155 and 11155 respectively.

Figs 5 - 6. "Chonetes" sp. Ventral views UNE F11072, 11071 .

Figs 7 - 9. Megastrophia hilzae sp. nov. Dorsal, ventra1, and mold of pedicle valve interior of holotype UT 94095 and paratypes UNE 11049 and 11050.

Figs 10, 14. Hipparionyx (?) sp. Brachial valve interior, and shel1 ornament UNE 11068 and 11069 .

Figs 11 - 13. Meristelza sp. Posterior, lateral, ventral views of UNE 11170 . 


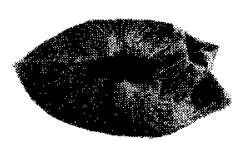

1

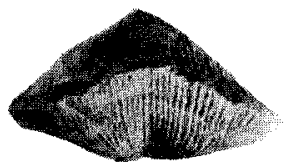

2

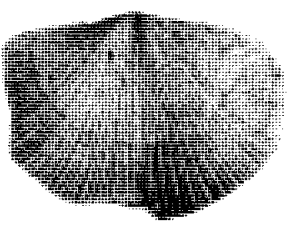

3

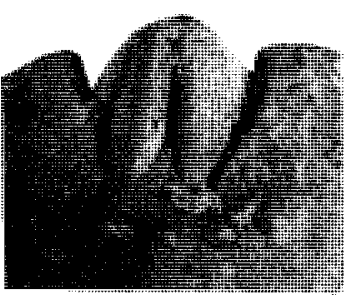

4

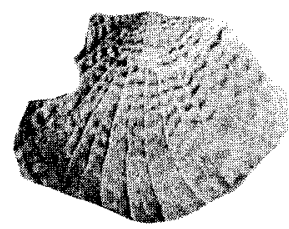

5

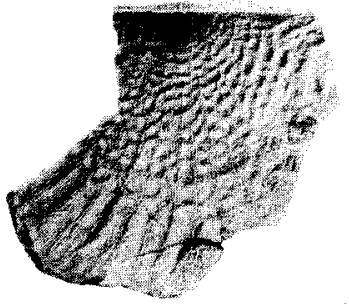

6

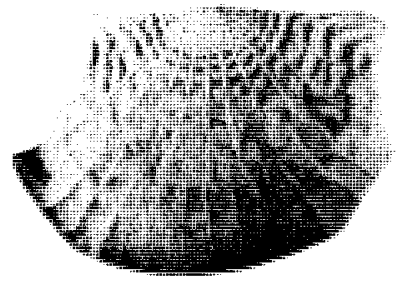

7

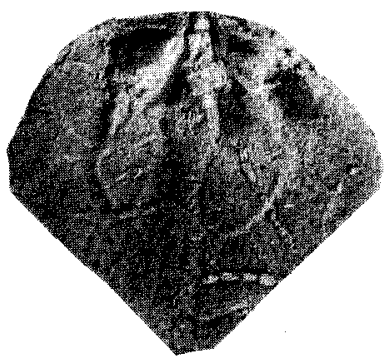

8

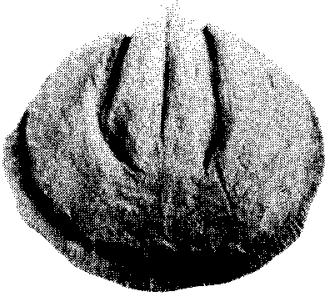

9

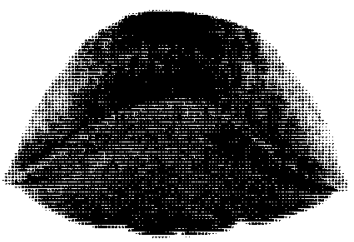

10

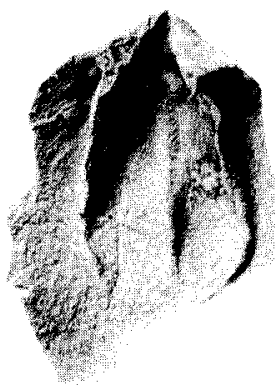

11

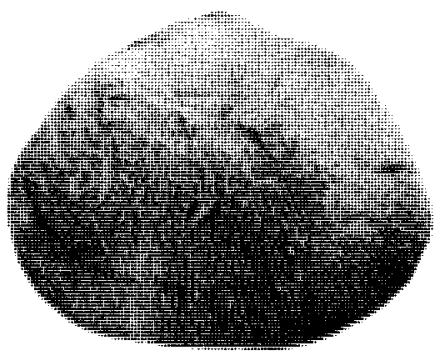

12

PLATE 1 

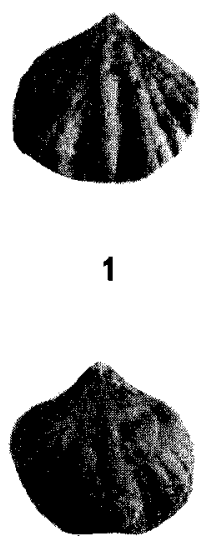

2

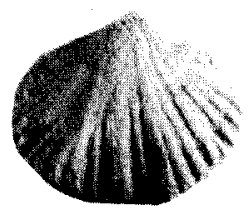

3

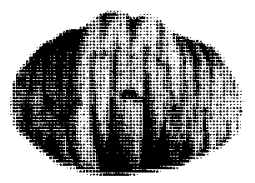

4

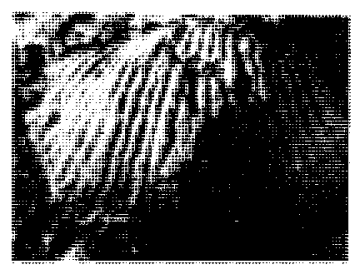

5

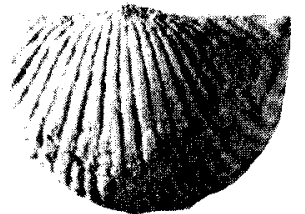

6

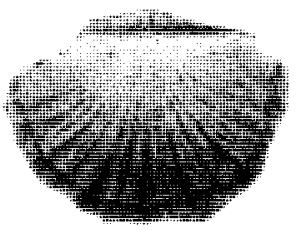

7

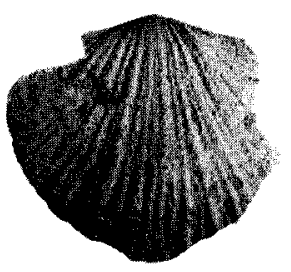

8

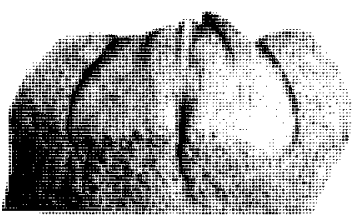

9

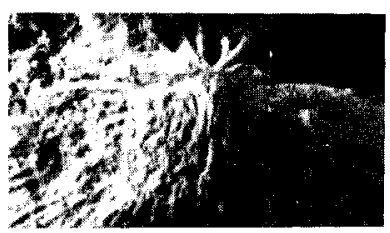

10

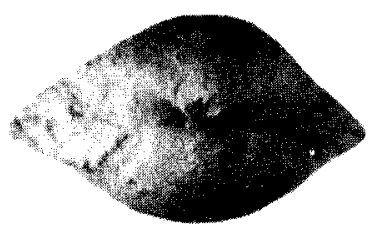

11

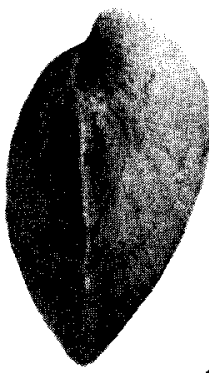

12

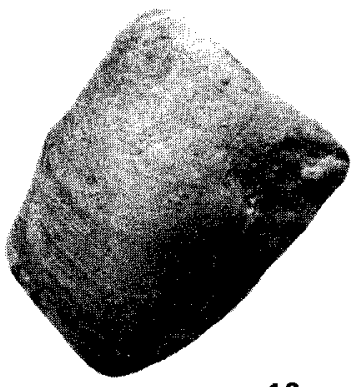

13

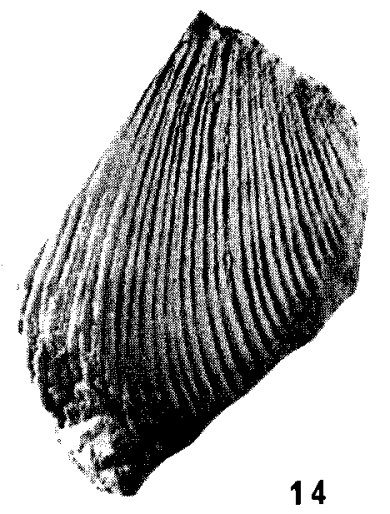

14 


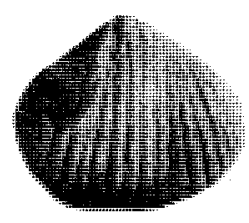

1

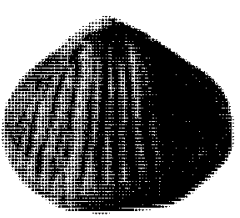

2

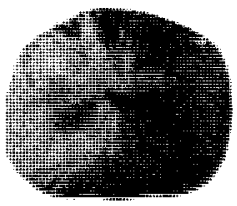

3

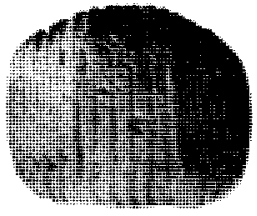

4

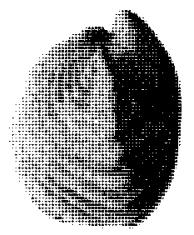

5

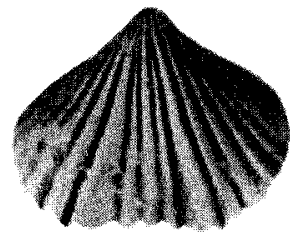

6

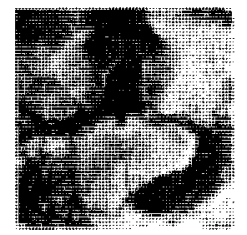

7

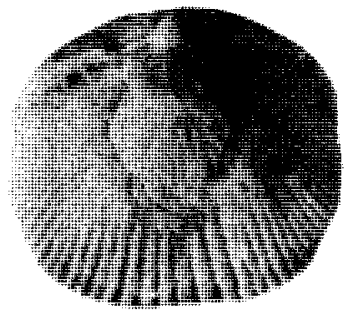

8

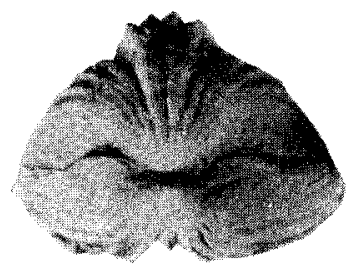

9

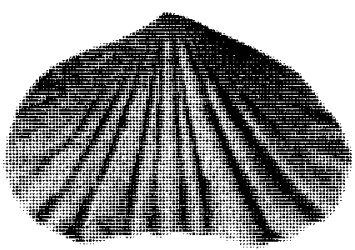

10

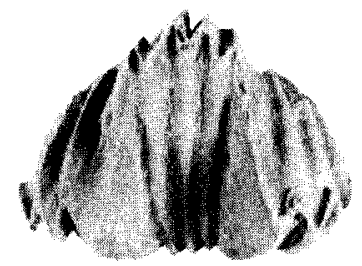

11

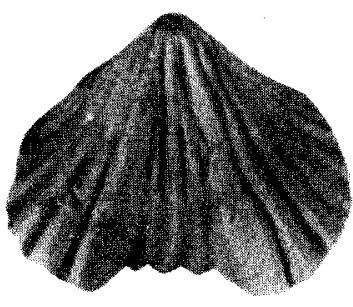

12 


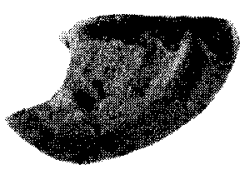

1

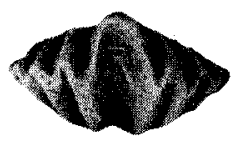

2

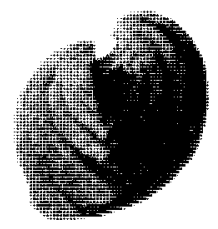

3

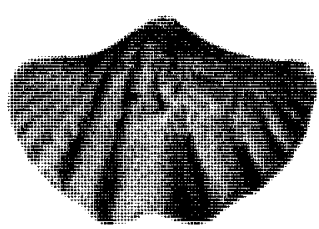

4

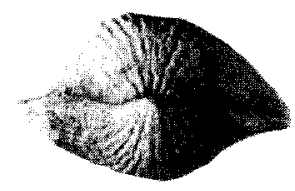

5

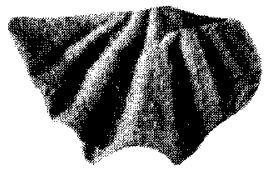

6

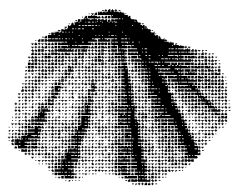

7

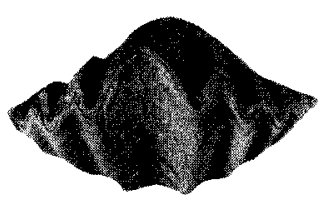

8

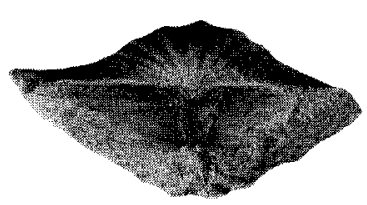

9

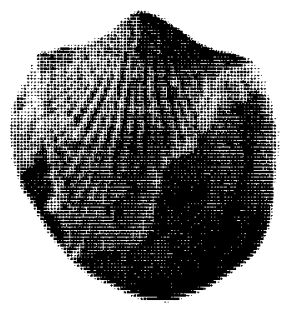

10

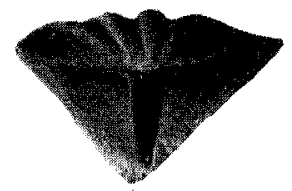

11

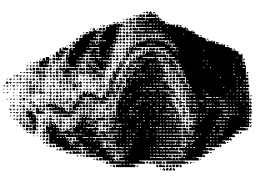

12

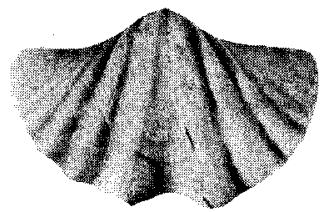

13

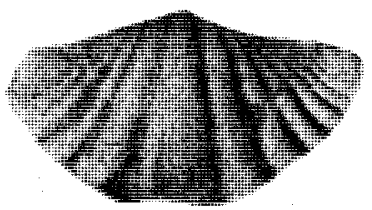

14

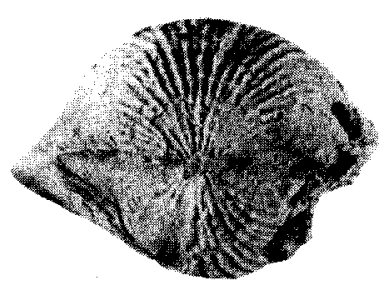

15

PLATE 4 
PLATE 3

A11 specimens except 7 were whitened with ammonium chloride. All figures $\times 1 \frac{1}{2}$ except $5,6,9-12 \times 2$.

Figs 1 - 4, 7 - 8. Hebeotoechia hibbensis sp. nov. $1-4$, Ventral, dorsal, posterior, and anterior views, holotype UT 51416. 6, Transverse section of cardinal process, paratype UNE F 11123. 8, Cast of pedicle valve interior, paratype UT 51421.

Figs 5 - 6, 9 - 12. Machaeraria sp. cf. M. formosa (Hall, 1857) 5 - 6, Lateral and ventral views, UNE F 11088. 9 - 12, Posterior, ventra1, anterior, and ventral views of UNE 11077, 11089, 11077 and 11077 respectively.

PLATE 4

Al1 specimens were whitened with ammonium chloride.

A11 figures $x 2$ except 1, 6 and $11 \times 3$.

Figs 1, 6, 11. Cyrtina heteroclita (Defrance, 1828) Latera1, dorsa1, and posterior views of UT 51393 , UNE F11189 and UT 51393 respectively.

Figs $2-4,7-9,12$ - 14. Acrospimifer banksi sp. nov. Anterior, lateral, dorsal, dorsal, anterior, posterior, anterior, ventral, and ventral views of paratypes UNE F 11210; 11212, UT 51400, UT 94096 (holotype) UNE F 11213, UT 51400 and UNE F 11215.

Figs 5, 10, 15. Atrypa sp. cf. A. retioularis (Linnaeus, 1758). Anterior, ventral, and anterior views of UNE E11179, 11179 , and 11182 . 